\title{
Ring artefact in multidetector CT
}

\author{
Suheil Artul ${ }^{1,2}$
}

${ }^{1}$ Radiology Department, EMMS Hospital Nazareth, Nazareth, Israel

${ }^{2}$ Faculty of Medicine, Bar-llan University, Nazareth, Israel

\section{Correspondence to}

Dr Suheil Artul,

suheilartul@nazhosp.com/ Suheil_artul@hotmail.com

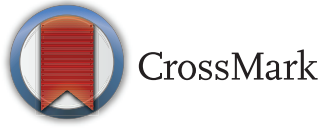

To cite: Artul S. BMJ Case Rep Published online:

[please include Day Month Year] doi:10.1136/bcr-2013201379

\section{DESCRIPTION}

High-resolution tomographic images acquired with a digital X-ray detector are often degraded by the so-called ring artefacts.

Ring artefacts are the concentric rings superimposed on tomographic images.

Artefacts in general can seriously degrade the quality of multidetector CT (MDCT) images, sometimes to the point of making them diagnostically unusable and can mislead to wrong diagnosis. Ring artefact is of a popular one. It is necessary to understand why ring artefact occurs and how it can be prevented or fixed.

Areifacts in CT generally are classified into four types based on the origin of cause ${ }^{1}$ : (1) physicsbased artefacts, (2) patient-based artefacts, (3) scanner-based artefacts such as ring artefact, which result from imperfections in scanner function and (4) helical and multisection artefacts.

Ring artefacts happen when at least one of the detectors is out of calibration on a spiral MDCT scanner or when one of the detectors is out of place, so that the detector will give a consistently erroneous reading at each angular position, resulting in a circular artefact (figures 1 and 2).

When ring artefact happens we can fix the problem by recalibration of the scanner and if this is not enough to fix it we need a service to change or reposition the detector in the right place.

Selecting the correct scan field of view may reduce the artefact by using calibration data that fit more closely to the patient's anatomy.

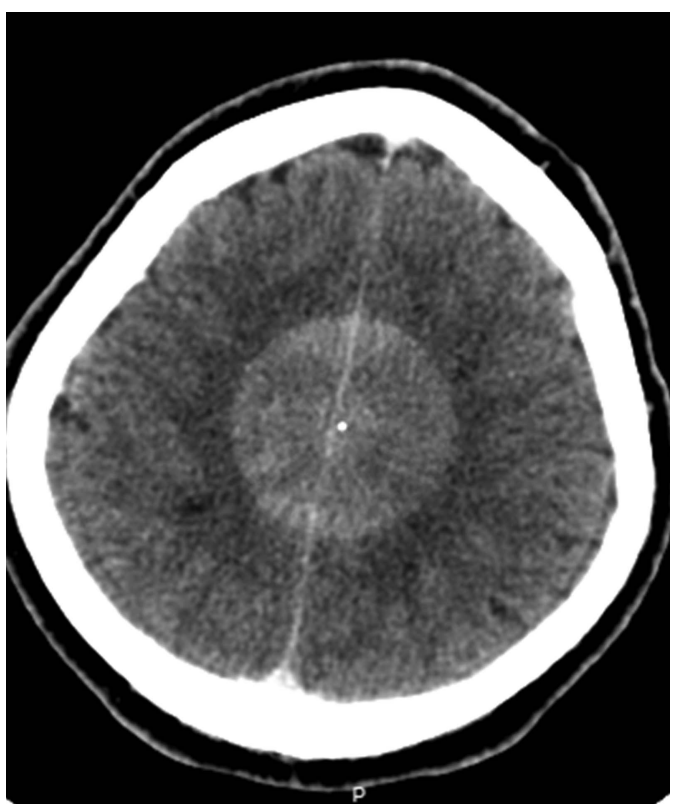

Figure 1 Axial CT slice of the brain showing ring artefact resembling a rounded enhancing mass.

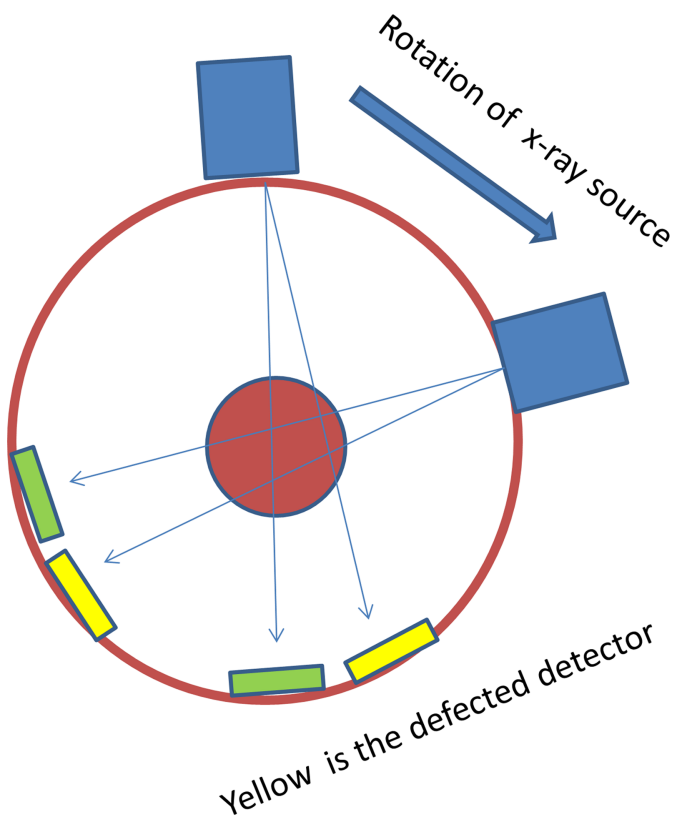

Figure 2 Schematic picture showing how ring artefact is produced.

The correction of ring artefacts by software is still in doubt, and none is entirely suitable for correcting different types of ring artefacts without introducing processing distortion of the image structure. $^{2}$

\section{Learning points}

- Ring artefacts can degrade the quality of a multidetector CT image and can sometimes make the interpretation of the image not possible.

- Fixation of this artefact can be made by recalibration of the scanner or by changing the malfunctioned detector.

- Prevention of this artefact using some software is limited.

Competing interests None.

Patient consent Obtained.

Provenance and peer review Not commissioned; externally peer reviewed.

\section{REFERENCES}

1 Barrett JF, Keat N. Artifacts in CT: recognition and avoidance. Radiographics 2004;24:1679-91.

2 Anas EM, Lee SY, Hasan K. Classification of ring artifacts for their effective removal using type adaptive correction schemes. Comput Biol Med 2011;41:390-401. 
Copyright 2013 BMJ Publishing Group. All rights reserved. For permission to reuse any of this content visit http://group.bmj.com/group/rights-licensing/permissions.

BMJ Case Report Fellows may re-use this article for personal use and teaching without any further permission.

Become a Fellow of BMJ Case Reports today and you can:

- Submit as many cases as you like

- Enjoy fast sympathetic peer review and rapid publication of accepted articles

- Access all the published articles

- Re-use any of the published material for personal use and teaching without further permission

For information on Institutional Fellowships contact consortiasales@bmjgroup.com

Visit casereports.bmj.com for more articles like this and to become a Fellow 